\title{
EXPLORING TALENT MANAGEMENT TRENDS IN ORGANISATIONS WORLDWIDE: A SYSTEMATIC LITERATURE REVIEW
}

\author{
SHEETAL RAMPAL ${ }^{1} \&$ DR. NITIN ARORA ${ }^{2}$ \\ ${ }^{I}$ PhD Scholar in Management, Amity International Business School, Amity University, Noida, India \\ ${ }^{2}$ Professor in HR Department, Amity International Business School, Amity University, Noida, India
}

\begin{abstract}
In the recent past, it has become a trend that the talented employees of any organisation have a tendency to leave it due to lack of expected growth and work satisfaction. It remains a challenge for these organisations to think of the various practices which can enable the retention of their talented workforce and actively contribute in the success of the organisations. Talent management has come up as a pertinent management field focussed on the growth and development of their employees. It incorporates the activities concerned with the attraction, development and retention of the employees who are competent and talented. Organisations are now actually perceiving the significance of their human capital and investing a huge amount of their funds in adopting diverse talent management practices thereby gaining a competitive advantage. This paper tries to make a sincere effort to comprehend the development of the concept of talent management since the time of its origin around the latter half of nineties through a systematic assessment of the existing literature in this field. It further tries to get an insight into different practices being adopted by the organisations in many sectors and their impact on the employees through the study of the researches being done by various academicians.
\end{abstract}

KEYWORDS: Talent Management, Human Capital, Attraction, Development, Retention, Performance

Received: Jun 09, 2020; Accepted: Jun 29, 2020; Published: Aug 07, 2020; Paper Id.: IJMPERDJUN2020683

\section{INTRODUCTION}

Organisations worldwide have been struggling to retain their talented employees who have a tendency to leave their jobs due to lack of any progress or growth in their career. This has made the companies to ponder upon the reasons responsible and hence the concept of managing the talent comes into picture. Talent management is becoming a significant domain of HR management which is being accepted by the various organisations worldwide to develop and retain their talented human capital. They are now following certain talent management practices to build the talent pool in the form of their employees and simultaneously gaining a competitive advantage by judicious utilisation of this pool. Talent management can be implemented successfully by only those organisations which have a learning minded culture and support open communication, creative environment and proper knowledge management. These organisations which are established on the core values of thoughtfulness about the employee interests have a strong impact on the talent attraction as well as their retention [1].

\section{RESEARCH OBJECTIVES}

This review paper aims to study the various researches being done in the emerging field of talent management and the various practices involved in it. This study is purely qualitative based on a meticulous comprehension of various 
literature available in the line of talent managementto get a proper insight in this areaand how it impacts the employees working in any organisation. This is our sincere effort to show the trends of talent management by incorporating the following aspects in the paper:

- Origin and development of the concept of talent management (TM)

- Discussing the driving forces leading to TM

- Assessment of the research on impact of talent management worldwide

- Discussing the common TM practices based on review.

- Discussing the future research aspects in the TM field

\section{REVIEW OF LITERATURE}

\section{Conceptualisation of Talent Management}

Originating from the word 'talent' which is defined as an inherent or attained level of calibre, potential or competence of any person. Talent of an employee is something very unique as well as valuable from an organisational point of view.It is something which is not easily replaceable by any other resources from an organisational point of view. So, talented employees are of strategic importance to any firm and its really very important for organisations to utilize this talent in a proper way to get a competitive advantage [2].

As per Tansley [3],talent management as an area of research among the academicians is still quite recent although the organisations worldwide had already realized its importance many years back.That is the reason why till the starting of the $21^{\text {st }}$ century most of the research and studies on talent management was accessible through the reports prepared by famous global companies. Although nowdaysvarious management researchers are coming up with their analysis on how talent management impacts the overall performance of any organisation as well as employees' attitude towards their work [4].

If we go back to the origin of the term talent management, Beechler and Woodward[5] through their elaborate exploratory research revealed that this concept gained popularity in the late 1990s, when USA's famous management consulting firm Mc Kinsey \& Company published a report regarding the importance of talented employees. This particular report brought the focus of the business organisations in the direction of the fact that talented employees played a significant roleto gain success and competitive advantage. Their talent needed to be nurtured for retaining them. This report called "War for Talent" waspublished in the year 1998 which was prepared after compilation of the data based on extensive research on seventy-sevenfirms of various industries. Almostsix thousandmanagers and executives were contacted and also supporting case studies of these companies agreed to the fact thatwere more in demand than the supply [6].The HR consultants did many studies in the following years to have an insight towards the reasons behind talent shortages which further led to the coining of some new terms like talent attraction and talent development as crucial parts of talent management.

\section{Defining Talent Management}

Although the talent management has become a relevant field in the HR department,still the researchers are not certain about the exact definition of this very term.There are many forms of this term as per the researchersbut the basic aspect 
remainsthe same that is to integrate certain practices to acknowledge the relevance of the talent of employees for the organisational success through a positive change in the working attitude of employees([7],[8]).

Schweyer [9] defines talent management as a practice which incorporates in it almost all the major processes of HR management starting from attraction and selection till development and continuation of the workforce in any organisation.

Lewis and Heckman [8]came up with a concept that talent management is a collection of many HR activities involving the process of recruitment and selection, training and development and further succession planning of the employees with the right talent.

Stockley [10] further elaborates that talent management is a deliberate and conscious approach for the attraction, development and retention of the human capital with the required talent to fulfil the current and anticipated demands of any company.

Another definition which is given by Colling and Mellahi [7] states that talent management is a strategy to find out the significant positions in any organisation in proper way,filling these positions through the nurturing of talent pool possessing high potential and further developing capable human resources to help in filling these with employees committed to their job. These are the positions which help in the sustained development of the organisations.

Cappelli [11] also refers to the talent management as an ongoing exercise through which the organisations forecast the human capital requirement for their key positions and further fill them with the right kind of talent for the sustained growth.

Based on the concept and definitions given by the famous researchers as discussed above, we try to infer that talent management of employees is an integrated approach focussing on the key positions' identification,selection of appropriate employees withthe competencies and right talent followed by their training and development for retaining that talent.This leads to the achievement of competitive advantage of the organisations through the constantstrengthening of the talented employees.

\section{Driving Force for Adopting Talent Management Practices}

Organisations worldwide cannot deny the value of implementing the practices of talent management because the results of various academic researches and famous company reports have suggested that these practices not only help in retaining the talented workforce but also help the organisations in achieving competitive advantage and better performance resulting in more profits.Farley [12] suggested that talent management incorporated all the practices which optimised the human capital available within the organisation. These practices commenced with the recruitment of suitable candidates and went on to the training, performance management, career planning and succession management. The HR department must act as the driver of talent management by helping the line managers in proper management of the available talent which is the heart of any organisation translating its goals to the needs of the workforce and gaining profits also. new approach focussed primarily on the attraction development and retention of their employees.

As per a research article by McCauley and Wakefield [13] there is a constant challenge in front of the organisations worldwide to acquire and retain the right talent. For making any talent management program to be successful there should be proper coordination between the various departments of the company. They asserted that proper leadership 
development programs can make them understand their own capability as well as gain a mindset for talent. There are many driving forces making the organisations realize the value of carrying out talent management practices.

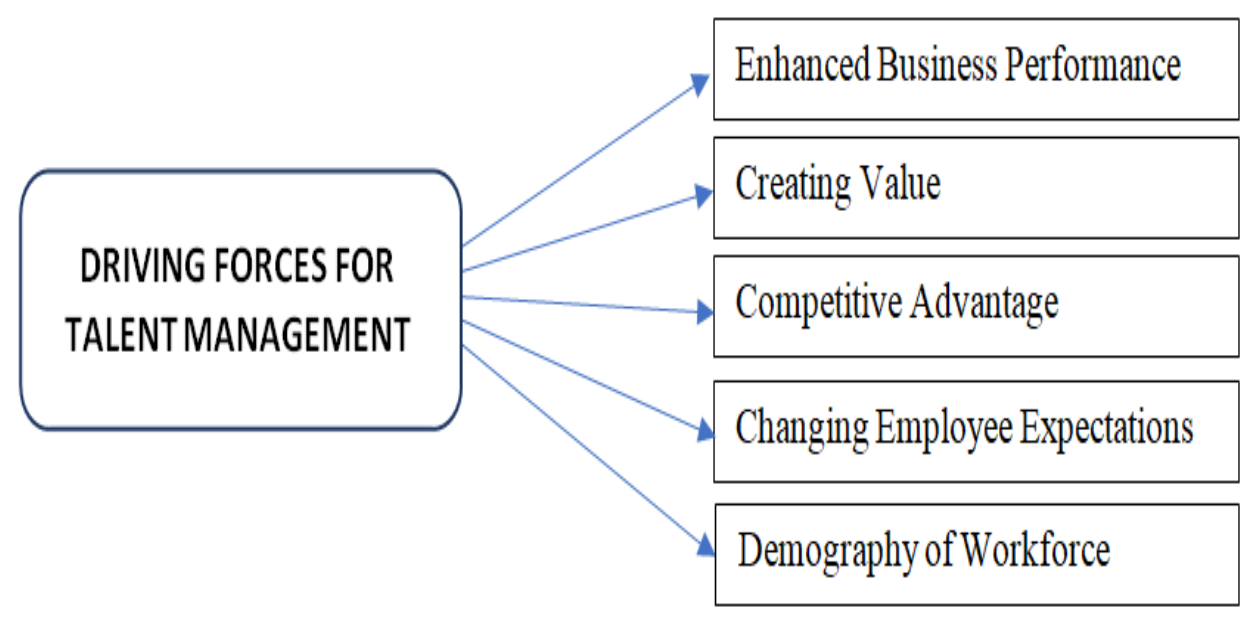

Figure 1

\section{Some of the Major Driving Forces as Shown in Fig-1 are Briefly Described as:}

\section{Enhanced Business Performance}

The organisations can enhance their businesses by infusing a certain percentage of their available resources in the talent management of their employees and also improve their return on investment. Iles et al [14] did a study in seven multinational companies situated in Beijing and found that although the policies of human resource management and talent management were quite similar in the sense that they both aligned them with the organisational business strategies still talent management differed from HR in its new people focused approach. Talent management is more concerned with the proper role allotment and providing right talent at the key functions as per the requirement. This gave positive results through an increase in theoutput of employees and the organisation.

\section{Creating Value}

Ganae and Haque [15] insisted that the implementation of talent management activitiesled to an increase in the knowledge base of the employees and a better talent if retained can raise the financial value of the organisation. These practices make the employees motivated who give their best output in turn creating the organisational value through revenues and earnings.

\section{Competitive Advantage}

This aspect plays an important driving force for talent management which helps a company to stand out. Stahl et al. [16] did a survey in 37 companies of different organisations in North America, Europe, and Asia to find out the talent management practices adopted by them. They focussed on how they developed their talent pool and noticed that some set of practices like recruitment, training and retention management led to provide these companies an extra edge in competitive world if they made them an integrated part of their HR strategy. Almaitah et al. [17] did a research in top ten firms of Jordan to conclude that if talent management was integrated with the strategies of business at corporate level, a very good level of competitive advantage can be reached. 


\section{Change in Employee Expectations}

Employees today have very different and high expectations from their employers than what was usually seen in the past. They just don't want their salaries but also remain anxious regarding their career development and work-life balance.Although it becomes a challenge for the organisation but through the talent management practices, they can try to meet these expectations. Nilsson and Ellstrm [18] asserted that by adopting the talent management practices, organisations in achieving their long-term strategic objectives. It is must for them to realise the individual training needs and employee development once the required talent is identified for achievement of organisational success.

\section{Demography of Workforce}

As the businesses are going global the demographic changes are taking place in the workforce hired. Organisations have to deal with racial diversity as well as increasing female employees. This shift in demographics is posing a challenging competition amongst different organisations which forces the employers to have clear policies regarding the talent management practices for their employees[19].As per a research by Pricewaterhouse Coopers[20] millennials will form half of the workforce globally by the starting of next decade whose demands for career advancements,work-life balance and intention to leave will push the organisations to adopt the practices of talent management.

\section{Effect of Talent Management on Various Organisations}

We are here trying to review the various literatures in the form of research papers written by different authors focussing on how the implementation of practices of talent management have an effect onthe organisation and employees working there. These studies have been done in various countries of the world including India in the last ten to twelve years and help us in having a broader insight into the prevailing trends in talent management.

In this context, Garrow \& Hirsh [21] advocated the fact that a clear focus for recruiting the most appropriate candidateto fit in the key position is essential for adopting talent management in any organisation.The areas under focus should be the ones which demand proactive approach in deciding about the strategies to acquire, nurture and further retain the employees who further facilitate in organisational goals. 'Fit' refers to the tuning between the HR policies and practices so that employer and employee share a common platform in attaining the strategic objectives of the organisation.

According to Phillips and Roper [22] who did a study in the sector of real estates in America submitted that companies are realising nowadays that their human capital or workforce in the form of their employees are brand themselves who showed great results through increased employee engagement and level satisfaction in the job through the acquisition of talent management activities whichinclude acquiring, developing, engaging, and retaining the prospective workforce.

Langenegger et al. [23] studied the various strategies of talent management and their impact on theperformance of organisationfocusing on companies in Switzerland. They came to a conclusion that the strategies of managing talent with an aim of development and retention of employees positively affected the level of job commitment and satisfaction as the human resource outcome of company's performance and the strategies of talent management emphasising on the corporate objectives had positive outcomes in terms of profit and attractiveness.

Beheshtifaar et al. [24] insisted that the talent management can be decisive about the key leadership roles which can be worth for the progress of competitive aspects of the company. They further concluded through their research based 
in Iran that talent management can be divided into three important fields comprising of recruitment of talent, development of that talent and thirdly the maintenance which altogether lead to the success of any company.

Another research which was done by Koketsu and Rust [25] in the municipality of Capetown, South Africa reported that there was a shortage of talent management practices in this department for the retention of workforce which was talented. These weremainly career and succession management activities as well as recognition which were essential for talent management of the employees. This resulted in a negative outcome as far as the commitment, satisfaction and work involvement of the employees were concerned and resulted in increased intentions of turnover.

Maya and Thamilsevan [26] through their research in the top five ranking companies of information technology in India reported that these focussed largely on the strategies of performance management and employee recognition as a part of the talent management practice. This resulted in a better financial performance as well as effectiveness compared to their peer companies. Bedia and Padmavat [27]tried to do a comparison of the practices of talent management being followed in the private and public sector companies of India and concluded that these practices helped public sector employees through better engagement enabling them to face the challenges and competition posed by the private sector workforce.

According to Dhanabhakyam and Kokilambal [28] there are some common talent management practices followed in four important sectors in India comprising Manufacturing, IT, Banking and healthcare. These start from the recruitment of the employees, selection of the required candidates and then followed by the training, performance management and compensation management so that the most suitable person with right skill and talent gets positioned in the organisation and can be retained. Fakrhuddin[29] reportedthat talent management practices like performance management, open climate and communication, development of employees had a strong positive influence on the success of any organisation. These success factors are increased employee satisfaction, engagement resulting in market share growth. His results were based on a research in a Petroleum company in Egypt.

Kibui et al. [30] did an empirical study in the state-run corporations in Kenya to conclude that talent management elements like performance and career development along with the competency mapping of employees resulted in almost thirty percent increase in the rate of retention. Talent management activities differ from the traditional HR practices which are more tactical dealing with day to day management while managing talent deals with morestrategy-basedaspects of the organisation. The four important constructs of talent management are identification of right talent, development of talent, succession planning and retention of talentand these are connected with each other and positively affect the outcome of any company financially and non-financially [31].

Isa and Ibraham [32] who conducted a study in the companies linked with Government in Malaysia revealed that training of employees together with career development and reward management were important talent management practices adopted there resulting in an increase in the engagement of the employees. Mensah[1]agrees that the ideology of talent management if accepted and implemented by the organisation actually affects the overall performance of the employees depicted through the increased motivation, commitment and involvement of the employees towards their job. Karunathilaka[33] insisted that even if the private organisations in Sri Lanka are having a competent and talented workforce, they still are not able to achieve the required outcomes in the absence of proper talent management practices which should be synchronised with the business strategies of the company. 
Karuri and Nahasun [34]did a research to know the effect of talent management in the Central Bank of Kenya asserted that the organisational outcome in the form of significant increase in job engagement and level of satisfaction amongst the employees was the key result of talent attraction, training and career management of employees. According to the study doneby Aggarwal and Jain[35] in different cement plants in India advocated that a mindset for talent management is required in influencing the satisfaction level of the employees towards their job. They summed up the talent management activities into workforce planning,recruitment,onboarding,performance management,360-degree appraisals, compensation and succession management.These were key practices which helped the organisation in the development and retaining of the competent employees which further led them to acquire a competitive advantage.

The activities incorporating the talent management practices can be categorised based on three dimensions strategic, ideological and structural through which an increased level of performance can be gained by the organisation. But the right kind of climate is a must for enhancing the creativity of the employees working there [36].

Tash etal.[37]revealed through their survey focussing the various Iranian oil companies that talent of employees can be managed by adopting the practices for talent attraction and development which led to a high level of satisfaction amongst the employees resulting in better performance in terms of brand building and competition with other companies.Kalaiselvan and Nachimuthu [38] further recommended that there are four ' $R$ 's in the full tenure of an employee working in any organisation consisting of recruitment, ripening, rewarding and retaining which comprisethe most essential dimensions of talent management which are driven by the business goals and influence the overall organisational output.

As per Pasha and Ahmed[39] who focused their research in the sector of information technology in India commented that there is constant global transformation of this sector and thus requires to invest an appreciable amount in the implementation of talent management practices starting with the recruitment process and goes on to the training, compensation management,succession planning and performance review of the employees with a proper alignment with the objectives of the organisation as a whole. Elia et al.[40]who did an exploratory study in the various banks of Lebanon under private sector noticed the same talent management practices being adopted there covering the entire tenure of the employees working there making them more satisfied with their job leading to overall financial gains for the company.

Van Zyl et al [41] insisted that an early clarity about the roles and responsibilities of the employees along with their accountability leads to a successful application of the talent management in any company. According to the research of Hitu and Baroda [42] based on the talent management practices which were followed in the selected banks of private enterprises in India there is a straight positiveresult of these practices on the employee motivation, satisfaction, and overall competency. Obeidet et al[43]did a survey in the private hospitals in Jordan to study the effectof implementing the practices of talent management on the organisational effectiveness. They reported that the dimensions of talent management which are mainlyattracting the talent,its maintenance and then its developmentinfluence the organisational effectiveness positively which can be observed in the form of job satisfaction and involvement of the employees.

Some of the major researches on talent management in various countries have been chronologically highlighted in the table 1: 
Table 1

\begin{tabular}{|c|c|c|c|c|}
\hline S. No & Year & Authors & Country & Study and Findings \\
\hline 1 & 2009 & Phillips and Roper & USA & $\begin{array}{l}\text { Acquiring TM activities lead to increased } \\
\text { employee engagement and enhanced } \\
\text { satisfaction. }\end{array}$ \\
\hline 2 & 2011 & Langenegger et al & Switzerland & $\begin{array}{l}\text { TM strategies increased commitment and job } \\
\text { satisfaction of employees }\end{array}$ \\
\hline 3 & 2012 & Beheshtifaar et al. & Iran & $\begin{array}{l}\text { TM decisive about future key leadership roles } \\
\text { leading to organisational success. }\end{array}$ \\
\hline 4 & 2012 & Koketso\& Rust & South Africa & $\begin{array}{l}\text { Career and succession management activities } \\
\text { as well as recognition important TM practices. }\end{array}$ \\
\hline 5 & 2013 & Maya \&Thamilselvan & $\begin{array}{l}\text { IT sector, } \\
\text { India }\end{array}$ & $\begin{array}{l}\text { TM practices like performance management } \\
\text { and recognition lead to organisational } \\
\text { effectiveness. }\end{array}$ \\
\hline 6 & 2013 & Fakhruddin & Egypt & $\begin{array}{l}\text { TM practices of training and career planning } \\
\text { have positive effect on employee engagement, } \\
\text { satisfaction and market share growth. }\end{array}$ \\
\hline 7 & 2014 & Kibui et al. & Kenya & $\begin{array}{l}\text { TM strategies of performance and career } \\
\text { management played a key role in employee } \\
\text { retention. }\end{array}$ \\
\hline 8 & 2014 & Isa and Ibrahim & Malaysia & $\begin{array}{l}\text { TM practices through training and } \\
\text { development, rewards and career management } \\
\text { result in better employee engagement. }\end{array}$ \\
\hline 9 & 2015 & Karunathilaka & Sri Lanka & $\begin{array}{l}\text { TM practices should be in line with the } \\
\text { business strategies of organisations for better } \\
\text { outcomes. }\end{array}$ \\
\hline 10 & 2016 & Ingram & Poland & $\begin{array}{l}\text { TMcan be applied successfully if there is } \\
\text { proper climate to enhance the creativity of } \\
\text { employees. }\end{array}$ \\
\hline 11 & 2016 & Tash et al. & Iran & $\begin{array}{l}\text { TM isessential strategy for competitive } \\
\text { advantage and brand building }\end{array}$ \\
\hline 12 & 2017 & Elia et al. & Lebanon & $\begin{array}{l}\text { TM related to employee satisfaction and } \\
\text { overall financial gains of the company }\end{array}$ \\
\hline 13 & 2018 & Hitu and Baroda & Banks, India & $\begin{array}{l}\text { TM enhances motivation, satisfaction and } \\
\text { competency of the employees }\end{array}$ \\
\hline 14 & 2019 & Obedient et al & Jordan & $\begin{array}{l}\text { Attracting and developing talent results in job } \\
\text { satisfaction and better involvement. }\end{array}$ \\
\hline
\end{tabular}

\section{Common Talent Management Practices}

The literature review done above gives us an overview of the different practices of managing talent all over the world in various sectors and how these have affected the employees and the organisations. We have found that some of thesepractices are very common in multiple organisationsbasically to acquire the right kind of talent and then develop that talent with an intent to retain it for gaining a competitive advantage and also increase the overall output. 


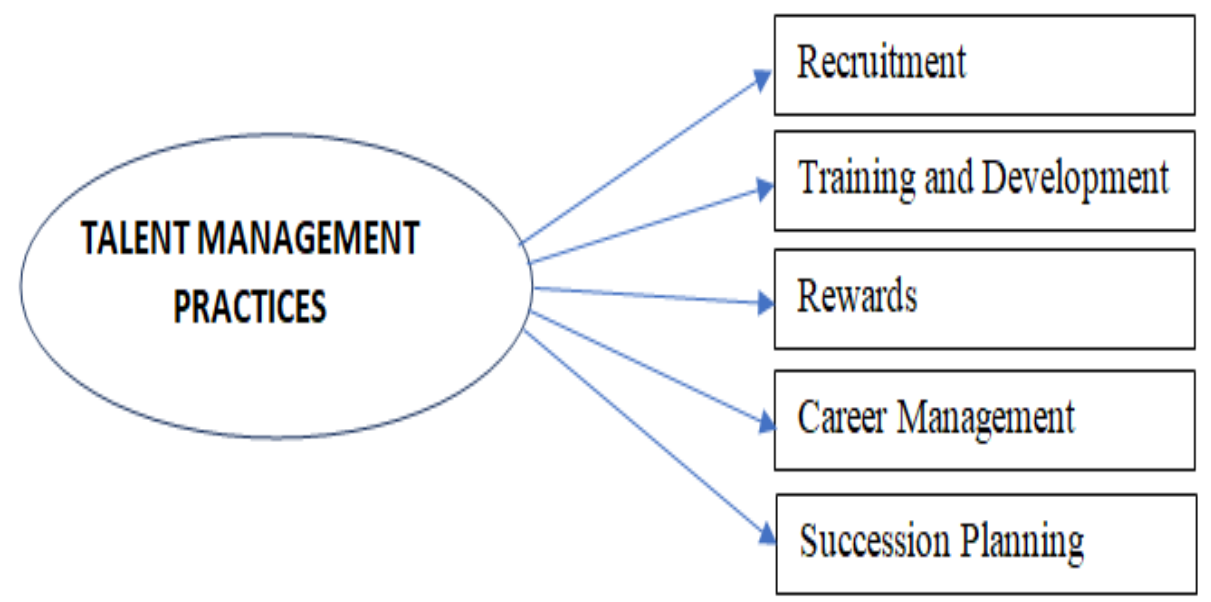

Figure 2

\section{Some very Common Talent Management Activities as Shown In Fig 2 are Briefly Summarised below}

\section{Recruitment}

According to Gamage [44] recruitment is a practice followed by the organisations which aims to come up with a group of job candidates who are competent and talented. The level of human capital working in any company depends on the type of candidates that have been attracted for recruitment there. Recruitment is basically the point of entrance of potential manpower.

Ekwoaba et al [45] reported that if proper recruitment path is adopted,it positively effects the performance of any organisation. As reported by Mustapha etal.[46]the practice of recruitment tries to fill the unoccupied positions with the relevant candidates and then aims to nurture themfor better retention in the organisations. This activityis successful only if its transparent, fair and properly planned for overall consistency and development of any organisation to achieve its goals.

\section{Training and Development}

According to the study of Nischitha and Rao [47],training can be conceptualised as a method of learning which incorporates development of new skills or techniques amongst the employees to increase their performance level. The employees are provided suitable trainingson frequent basis as per their needs for enhancing their output and consequently the organisational performance.

Gafoor et al [48]believe that the style of delivering any training and its design impact the effectiveness of any training program. It not only develops the required competence of any employee but also changes his or her attitude towards the work. Providing a high level of training to the employees leads to a definite effect on their job satisfaction levels, motivation and organisational commitment. This further reduces the absenteeism and an increased job performance level [49].

\section{Rewards}

Rewards are defined as any kind of benefit provided to the employees whether financial, non-financial or psychological in the exchange of his job in the organisation [50].Reward structure usually comprises the policies of payroll and salary administration, minimum wage, executive salaries and also team rewards. Reward Management is aimed at providing fair and consistent rewards as per their talent and value addition to the organisation [51]. 
The impact of rewards is that it increases the morale and job satisfaction of the employees which further reduces their turnover intentions and also improves the performance [52].

\section{Career Management}

It is a very methodical and detailed process involving the career development strategies of the organisational management which is actually focused on enhancing the skills, talents and productivity of their employees resulting in achievement of organisational goals. Career planning can be helpful only when the talents and ability of the employees are utilized to their full potential by the organisations. This would furtherincrease their morale leading to better job satisfaction and maximized output [53].

According to Vos and Dries [54] organisations establish many policies deliberately aiming to improve the value and efficacy of the careers of their employees. These policies and practices focus on knowing what actually are the demands of the employees from their careers, if the opportunities are provided depending on the ability and talent of the employee and then evaluating the results of these programs. These could be short term like career counselling by HR department or long term like providing trainings consistent with the company plans for motivation and satisfaction of the employee.

\section{Succession Planning}

Succession Planning identifies the required expertise to make sure that the leadership for all key positions is continued through an assessment and development of the available talent internally. The organisations adopt succession planning to plan for their future survival and competitiveness. They develop their talent poolfor future leadership roles and filling of key positions internally [55].

As reported by Ahsan [56], it is a system by which the organisations prepare a backup plan for replacing the important employee levels as there is always certain apprehensions in the minds of organisational management about the future key roles and the impact it could have on the proper business continuity. If implemented properly, succession planning helps in career development and promotions of employees resulting in their retention.

\section{CONCLUSIONS}

The detailed and systematic overview of the literature available on talent management reveals that for the success and the sustained growth of any organisation in today's fast changing and dynamic business scenarios implementation of proper talent management practices is of prime importance. These practices not only help the organisations in the attraction of the human capital with the right talent and skill which are an asset for the company but also lead the way of the company towards achieving its objectives and standing out successfully in front of their competitors. The researcher could get an insight and a better perspective of the proper definition of talent management and the most significant practices of talent management comprising recruitment of the suitable employees, their training and development, career management, rewards and succession planning. These practices are nowadays being implementedwhich are commonly implemented globally in the various sectors like banking, education, Information technology, healthcare sectors and even many stateowned and public sector companies. These are responsible for acquiring the right talent, developing the talent and leading to the overall organisational success. 


\section{FUTURE RESEARCH ASPECTS}

This particular research paper provides enough basis for further academic research in finding out the impact of this budding field of HR management on the job attitude of the employees working in any organisation. This can be measurable in terms of level of satisfaction, engagement and commitment of employees to their work or their intent to leave the organisation. These researches could be helpful for organisations globally to have a clear vision regarding the relevance of their manpower and to acknowledge their talent and skills and consequently, adopting the practices of talent management to address the tremendous challenge of retaining their talented workforce in the complex current business environments.There is much scopefor conducting empirical researches to assess the effect of the different talent management constructs on the overall performance and growth of the organisations.

\section{REFERENCES}

1. E. Gallardo-Gallardo, M. Thunnissen, \& H.Scullion, 'Talent management: context matters', The International Journal of Human Resource Management, DOI:10.1080/09585192.2019.1642645

2. J.K. Mensah, 'A “coalesced framework" of talent management and employee performance', International Journal of Productivity and Performance Management Vol. 64(4), 2015 pp. 544-566

3. C. Tansley, 'What do we mean by the term "talent" in talent management?', Industrial and Commercial Training, Vol. 43 (5), 2011, pp. $266-274$

4. S. Rampal and N. Arora, 'Impact of talent management on the job attitude of employees in Indian thermal power sector- $A$ proposed model', Journal of Business and management, 19 (7), 2017, pp21-30.

5. S. Beechler and I.C. Woodward, 'The Global War for talent', Journal of International Management, vol.15,2009, 273-285

6. E. Chambers, M. Foulon, J.Handfield, S. Hankin, and E. Michaels III, 'The War for Talent', The Mc Kinsey Quarterly3,1998, pp. $44-57$

7. D. G. Collings and K. Mellahi, 'Strategic Talent Management: A review andresearch agenda', Human Resource Management Review, 19: 4, 2009, pp.304-313

8. R.E. Lewis and R.J. Heckman, 'Talent management: a critical review', Human Resource Management Review, Vol. 16, No. 2, 2006, pp.139-154.

9. A. Schweyer, 'Talent management systems: Best practices in technology solutions for recruitment, retention and workforce planning,' New Jersey: John Wiley \& Sons, 2004.

10. D. Stockley, 'Talent management concept - definition and explanation [Online]'. Available from http://derekstockley.com.au/newsletters-05/020-talentmanagement. html accessed on Dec.3,2018

11. Peter Cappelli, 'Talent management for $21^{\text {st }}$ century', Harvard Business Review, March 2008

12. C. Farley, 'HR's Role in Talent Management and Driving Business Results', Employment relations today, Wiley Periodicals, Inc. Published online in Wiley Inter Science, 2005

13. C. McCauley and M. Wakefield, 'Talent Management in $21^{\text {st }}$ Century: Help your company find, develop and keep its strongest workers', The Journal of Quality and Participation,29(4),2006, pp-4

14. P. Iles, D. Preece. and X. Chuai, 'Talent Management and HRM in Multinational companies in Beijing: Definitions, differences and drivers', Journal ofWorld Business, 46: 2,2010 
15. M. U. Ganae, and M. I. Haque, 'Talent management and value creation: a conceptual framework, Academy of Strategic Management Journal.16(2),2017, pp1-9

16. G. K. Stahl, I. Björkman, E. Farndale, S.S. Morris, J. Paauwe and P. Stiles, 'Six Principles of Effective Global Talent Management', MIT Sloan Management Review,53(2),2012, 25-32.

17. M.A. Alma'aitah, W.H. Aljamal and F.S. Al-Shalabi, 'Talent Management and Competitive Advantage: The Moderating Effect of Knowledge Integration', International Journal of Computer Applications (0975 - 8887),66(11),2013

18. S. Nilsson and P. Ellstrom, 'Employability and talent management: challenges for HRD Practices', European Journal of Training and Development Vol. 36 (1),2011, pp. 26-45

19. T.J.E.I. Calo, 'Talent Management in the Era of the Aging Workforce: The Critical Role of Knowledge Transfer', Public Personnel Management, 37(4), 2008, pp403-416

20. PwC report available online at https://www.pwc.com/gx/en/hr-management-services/pdf/pwc-nextgen-study-2013.pdf

21. V. Garrow and W. Hirsh, 'Talent Management Issues of Focus and Fit', Public Personnel Management; Winter 2008; 37(4), pp 389

22. D. R. Phillips, and K.O. Roper, 'A framework for talent management in real estate', Journal of Corporate Real Estate, Vol.1(1),2009, pp7-16

23. Bethke-Langenegger, P. Mahler and B. Staffelbach, 'Effectiveness of talent management strategies,' European J. International Management, Vol. 5, No. 5,2011, pp.524-539.

24. M. Beheshtifar H.Y. Nasab and M.K. Moghadam, 'Effective Talent Management: A vital strategy to organisational success', International Journal of Academic Research in Business and Social Sciences, Vol. 2, No. 12,2012

25. L.P. Koketso and A.A. B Rust, 'Perceived challenges to talent management in the South African public service: An exploratory study of the City of Cape Town municipality', African Journal of Business Management, Vol. 6(6), 2012, pp. 2221-2233

26. M. Maya and R. Thamilselvan, 'Impact of talent management on employee performance and organisationalOrganizational Successefficiency in ITSP's - with reference to Chennai city', International Journal of Economics and Research, Vol. 10( 2),2013, pp. 453-461

27. D. D. Bedia and A. Padmavat, 'Comparative analysis of talent management practices in selected Public and private sector organisations,' International Journal of Multidisciplinary research in Social and Management Sciences Vol 1(4),2013, pp.919

28. M. Dhanabhakyam, and K. Kokilambal, 'A study on existing talent management practice and its benefits across industries', International Journal of Research in Business Management Vol. 2(7), Jul 2014, pp 23-36

29. H. Fakhreidin, 'The Effect of Talent Management on Organizational Success:A Comparative Study in the Petroleum Sector in Egypt,' Journal of US-China Public Administration, Vol. 10, No. 4,2013, 358-367

30. A.W. Kibui, H. Gachunga and G.H. Namusunge, 'Role of talent management on employee's retention in Kenya: A survey of state corporations in Kenya: Empirical review, International Journal of Science and Research Vol.3(2),2014, pp 414-424

31. J. Jyoti and R. Rani, 'Exploring talent management practices: Antecedents and consequences' International Journal of Management Concepts and Philosophy, Vol. 8(4),2014, pp.220-248

32. A. Isa and H.I. Ibrahim, 'Talent Management Practices and Employee Engagement: A study in Malaysian GLCs', International Journal of Business, Economics and Law Vol. 4(1),2014

33. K.S. Karunathilaka, M.S. Yazid,and A. Khatibi, 'A study of talent management as a strategic tool for private sector organizations in Sri Lanka', European Journal of Business, Economics and Accountancy, Vol. 3, No. 6,2015, pp63-76

34. M. Karuri and L. Nahashon, 'Effect of talent management on employee outcomes: A case study of central bank of Kenya,' The Strategic Journal of Business and Change management Vol. 2 (43),2015, pp 882-899

35. S, C. Agarwal and R. Jain, 'Talent Management Practices and Employee Satisfaction: A Study of Selected Cement Industries of Rajasthan,' Pacific Business Review International Volume 7, Issue 9, 2015, pp50-58 
36. T. Ingram, 'Relationships between Talent Management and Organizational Performance: The Role of Climate for Creativity Entrepreneurial Business and Economics Review, 4(3),2016, 195-205

37. M.S. Tash, E.N. Ali and M. Ahmadzadeh, 'Effect of Talent Management on Employees Performance in Oil Jam Petrochemical Complex -The mediating role of job satisfaction',International Journal of Economics and Finance; Vol. 8(6),2016, pp 226-230

38. K. Kalaiselvan and K.P. Naachimuthu, 'Strategic Approach to Talent Management: A Theoretical Model', Journal of Contemporary Research in Management Vol. 11(1),2016, ppl-23

39. M.P. Syed and B. Ahmed, 'A Study on Talent Management Strategies in IT Industry', International Research Journal of Engineering and Technology,4(4),2017

40. P.T. Elia, K. Ghazzawi and B. Arnaout, 'Talent Management Implications in the Lebanese Banking Industry', Human Resource Management Research,7(2),2017, pp 83-89

41. Van Zyl et al. The development of a talent management framework for the private sector, SA Journal of Human Resource Management. Vol 15(0),2017

42. Hitu and S. Baroda, 'Impact of Talent Management Practices on Employees' Performance in Private Sector Bank' International Journal of Management, 9 (1), 2018, pp. 16-21.

43. D.Obeidat, B. Yousef, H. Yassin, \&Masa'deh, 'The Effect of Talent Management on Organizational Effectiveness in Healthcare Sector'. Modern Applied Science, 12(6),2019

44. [44] A. S.Gamage, 'Recruitment and selection practices in manufacturing SMEs in Japan: An analysis of the link with business performance'. Ruhuna Journal of Management and Finance, 1(1),2014, pp 37-52

45. J. O.Ekwoaba, U. U.Ikeije, \&N.Ufoma, 'The Impact of Recruitment and Selection Criteria on Organizational Performance'. Global Journal of Human Resource Management Vol.3(2),2015, pp.22-33

46. Mustapha et al., 'The Impacts of well-Planned Recruitment and Selection Process on Corporate Performance in Nigerian Banking Industry', International Journal of Academic Research in Business and Social Sciences, Vol. 3(9),2013

47. Nischitha\&Rao, 'The importance of training and development Programmes in hotel industry', International Journal of Business and Administration Research Review, Vol.1(5),2014

48. Abdul Gafooret al., 'Impact of Training and Development on the Organisation Performance,' Global Journal of Management and Business Research Vol 11(7),2011

49. N. Thevanes and T. Dirojan, 'Impact of Training and Job Involvement on Job Performance' International Journal of Scientific and Management Research Vol. 1(1), 2018, pp1-10

50. J. Bratton, \& J. Gold., 'Human resource management: Theory and practice' (5th ed.).Basingstoke: Palgrave Macmillan.2012

51. David et al., 'Reward Management System'International Journal of Core Engineering \& Management Vol. 2(2), 2015

52. Martono et al., 'Remuneration reward management system as a driven factor of employee performance'International Journal of Business and Society, Vol. 19 (4), 2018, 535-545

53. E.Antoniu, 'Career planning process and its role in human resource development.' Annals of the university of petroşani, economics, 10(2),2010, 13-22.

54. Ans De Vos \& Nicky Dries, 'Applying a talent management lens to career management: the role of human capital composition and continuity', The International Journal of Human Resource Management,2(9), 2013,1816-1831

55. Y. Kim, 'Measuring the Value of Succession Planning and Management: A Qualitative Study of Multinational Companies'Performance Improvement Quarterly,23 (2)2010, pp. 5 - 31

56. M. Ahsan, 'Effective Recruitment and Selection along with Succession Planning towards Leadership Development, Employee Retention and Talent Management in Pakistan'. J Entrepren Organiz Manag 7: 233. doi:10.4172/2169-026X.1000233,2018 
